\title{
Isolation, Characterization, and Evaluation of Microsatellite Loci for Cultivar Identification in the Ornamental Pampas Grass Cortaderia selloana
}

\author{
Riaz Ahmad, Miki Okada, Jeffrey L. Firestone, Chris R. Mallek, and Marie Jasieniuk ${ }^{1}$ \\ Department of Plant Sciences, Mail Stop 4, University of California, Davis, CA 95616
}

\begin{abstract}
AdDitional INDEX wORDS. simple sequence repeat, SSR markers, Danthonioideae, Poaceae
AвSTRACT. We isolated and characterized microsatellite loci in the ornamental pampas grass Cortaderia selloana (Schult. \& Schult. f.) Asch. \& Graebn. for purposes of identifying cultivars and assessing genetic relationships among cultivars. Small insert genomic libraries were enriched for dinucleotide $(C T)_{n}$ and $(C A)_{n}$ repeats. Ninety clones were sequenced of which $76 \%$ contained at least one microsatellite with a basic motif greater than six repeat units. Nine primer pairs amplified 10 polymorphic and putatively disomic loci, and were used to genotype 88 individuals representing 17 named cultivars and four selections. In total, 93 alleles were detected with a maximum of two to 19 per locus. Effective number of alleles varied from 1.3 to 9.5. Observed heterozygosity ranged from 0.07 to 0.81 . The 10 microsatellite loci distinguished the majority of pampas grass cultivars. An unweighted pair group method with arithmetic mean (UPGMA) cluster analysis, based on proportion of shared alleles among individuals, revealed groups of cultivars corresponding to origin and morphological characteristics. With few exceptions, individuals of a single cultivar clustered together with moderate to strong bootstrap support (greater than 50\%). Interestingly, 'Pumila' from Europe and the United States formed separate clusters indicating independent origins. A large, diverse cluster with low bootstrap support consisted of selections and cultivars sold as seed, rather than potted or bare-root clonal plants. Primers designed for $C$. selloana amplified microsatellite loci in other Cortaderia Stapf species concordant with phylogenetic relationships among the species. Cross-amplification was $100 \%$ in $C$. jubata (Lemoine ex Carrière) Stapf; $77 \%$ in $C$. pilosa (d'Urv.) Hack. and C. rudiuscula Stapf; $66 \%$ in C. fulvida (Buch.) Zotov; and $55 \%$ in C. richardii (Endl.) Zotov and C. toetoe Zotov.
\end{abstract}

Cultivated pampas grass (Cortaderia selloana) is a popular landscape ornamental recognized for its impressive size and elegant inflorescences or plumes. The ornamental grass is native to South America but is grown around the world in regions with mediterranean and temperate climates, including areas of Africa, Australia, Europe, New Zealand, and North America (Cabrera, 1953; Costas Lippman, 1976; Hitchcock and Chase, 1950; Robinson, 1984). Cortaderia selloana was first introduced into cultivation in the early 1800s when the Scottish horticulturalist James Tweedie sent plants he collected in Argentina to botanical gardens in Scotland, England, and Ireland (Costas-Lippmann, 1977; Smyth, 1908). Pampas grass became the quintessential ornamental grass in English gardens of the Victorian era and continues to be widely grown in the British Isles and other areas of Europe (Greenlee, 1992; Grounds, 1979, 1998; Hornback, 1994). Cortaderia selloana was first introduced into North America about 1848 in southern California, where it was commercially grown for its plumes until the end of the century. It then came to be cultivated as a specimen or accent plant in lawns and gardens, and a hedge or windbreak around estates and property lines (Hornback, 1994; Madison, 1992). Worldwide, pampas grass is one of the most popular and well-known of ornamental grasses (Darke, 2004; Greenlee, 1992; Grounds, 1979, 1998; Oakes, 1990).

\footnotetext{
Received for publication 8 Dec. 2005. Accepted for publication 29 Apr. 2006. We thank the Grassland Research Station Zubri, Czech Republic; Huntington Library and Gardens, California; Ken's Nursery, California; Los Angeles County Arboretum, California; National Botanic Gardens at Glasnevin, Ireland; Pacific Nurseries, California; Royal Botanic Garden Edinburgh, Scotland; Sir Harold Hillier Gardens, England; Strybing Botanic Garden, California; Univ. of California Botanical Garden at Berkeley; Univ. of Oxford Botanic Garden, England; and Youngmark Nursery, California, for providing plant material for DNA analyses. Financial support for this research was provided by the UC IPM Exotic/Invasive Pests and Diseases Research Program.

'To whom reprint requests should be made. E-mail: mjasien@ucdavis.edu
}

The genus Cortaderia consists of $\approx 24$ species native to South America, New Zealand, and New Guinea (Barker et al., 2003; Connor and Edgar, 1974; Lyle, 1996). Cortaderia selloana, the type species, is highly polyploid with $2 n=8 x=72$ (Connor, 1983; Connor and Edgar, 1974) and has a gynodioecious to near dioecious or subdioecious breeding system (Connor, 1973; Costas-Lippmann, 1976). Hermaphroditic plants are effectively self-incompatible, setting minute quantities of seed when selfpollinated (Costas-Lippmann, 1976). Both pollen and seeds are dispersed by wind. Seeds are light and may be dispersed as far as 20 miles (Connor, 1973; DiTomaso et al., 1999). Hybrids can be easily produced with other Cortaderia species, including species differing in ploidy level, and have been found to be vigorous (Connor, 1983). The outcrossing nature of the breeding system, wind-dispersed pollen and seeds, and wide geographic distribution (Costas-Lippmann, 1976) suggest pampas grass populations in the native range of South America contain large amounts of genetic diversity. Considerable genetic diversity, together with the popularity and long history of cultivation of this species, may partially explain why so many named cultivars are available in cultivated pampas grass, in contrast to other ornamental grasses. To date, at least 20 ornamental pampas grass cultivars varying in sex expression, mature plant height, cold hardiness, foliage color and variegation, and plume color, shape, and size are recognized (Darke, 1999, 2004; Greenlee, 1992; Grounds, 1998; Oakes, 1990).

Because ornamental pampas grass is an outcrossing species, nurseries propagate the majority of cultivars as vegetative clones and sell potted or bare-root plants to ensure cultivar identity. However, a few cultivars are propagated and sold as seed. Seedpropagated cultivars often consist of plants with pink to purple plumes, in contrast to the white or silver plumes produced by most cultivars. The performance and integrity of ornamental plantings derived from seed are far less reliable than those derived from 
clones because plants derived from seed are more genetically diverse, often vary in the phenotypic traits that normally characterize cultivars (Hornback, 1994), and may not identify strongly with any cultivar if hybrids. Cultivar integrity is sometimes further confounded by careless seed dealers that substitute one Cortaderia species for another (Greenlee, 1992).

Currently, cultivar identification in ornamental pampas grass is based on vegetative and reproductive characteristics (Darke, 2004; Greenlee, 1992; Grounds, 1998; Oakes, 1990). Although such traits can readily distinguish cultivars in species with few cultivars of distinct phenotype that breed true or are clonally propagated, morphological characters are no longer sufficient to clearly identify all pampas grass cultivars and possible hybrids. The large number of commercial cultivars, some sport mutations of others, and increasing numbers of selections that are propagated and sold by seed require molecular markers for accurate genotyping and cultivar assessment. Microsatellites, or simple sequence repeats (SSRs), are particularly well-suited for identification of cultivars and hybrids in outbreeding, genetically variable species, such as $C$. selloana. Microsatellites are highly reproducible and polymorphic multiallelic markers with codominant inheritance, and have been shown to be highly discriminatory for cultivar identification and testing in ornamental species (e.g., Becher etal., 2000; Esselink et al., 2003; Smulders et al., 2003). In this paper, we describe the isolation and characterization of microsatellite loci from an enriched genomic library of $C$. selloana, and the development of markers for cultivar identification in ornamental pampas grass. We also report on the power of the microsatellite markers to identify genetic relationships among a representative set of commercially available pampas grass cultivars and selections from Europe and the United States. Finally, we assess the cross-amplification of the microsatellite markers in six other Cortaderia species, namely, C. fulvida, C. jubata, C. pilosa, $C$. richardii, $C$. rudiuscula, and $C$. toetoe.

\section{Materials and Methods}

Plant material and DNA extraction. Plants, seeds, and leaf samples of ornamental pampas grass were obtained from nurseries, garden centers, mail-order outlets, internet sites, and botanical gardens in Europe and the U.S. In total, 88 individuals representing 17 named cultivars and four selections designated "Pink," "Sterile," "Super Pink," or "White" were genotyped (Table 1). Leaves of 56 individuals from two naturalized populations of C. selloana in California (30 from Salinas, 26 from La Jolla) were also collected and genotyped to evaluate markers for disomic inheritance. All leaf samples were dried in silica gel, a colloidal form of silica that has high moisture-absorbing properties, for shipping or transport before DNA extraction (Chase and Hills, 1991). Seeds were germinated in the greenhouse and leaf tissue collected from seedlings. Microsatellite-enriched genomic libraries were constructed from a plant of $C$. selloana from Red Bluff, Calif. Leaf samples of C. fulvida, C. pilosa, C. richardii, $C$. rudiuscula, and $C$. toetoe were obtained from botanical gardens and nurseries in the British Isles and the U.S. Leaves of $C$. jubata were collected from naturalized populations in California.

Genomic DNA was extracted from 300-400 mg of dried leaf tissue using the CTAB procedure of Doyle and Doyle (1987) with addition of $10 \mu \mathrm{L}$ of Proteinase $\mathrm{K}$ to each sample after addition of CTAB buffer. DNA quality and quantity were determined visually from band intensities following $1.0 \%$ agarose gel electrophoresis and ethidium bromide staining.
MICROSATELLITE-ENRICHED LIBRARY CONSTRUCTION AND PRIMER DESIGN. Genomic libraries enriched for $(\mathrm{CA})_{\mathrm{n}}$ and $(\mathrm{CT})_{\mathrm{n}}$ repeat motifs were constructed from DNA of $C$. selloana following the methods of Ahmad et al. (2003) and Hamilton et al. (1999). In summary, $15 \mu \mathrm{g}$ of genomic DNA was double-digested with the restriction enzymes RsaI and NheI. DNA fragments in the size range of 300 to 800 base pairs (bp) were dephosphorylated and ligated to adaptors, following Hamilton et al. (1999). Fragments containing microsatellites were selected by hybridization with biotinylated-oligonucleotides complementary to the repetitive sequences $\mathrm{CT} / \mathrm{AG}$ and $\mathrm{CA} / \mathrm{GT}$, and recovered by magnetic beads linked to streptavidin. Fragments were then amplified by PCR, ligated into pCR 2.1 Topo cloning vector (Invitrogen, Carlsbad, Calif.), and chemically transformed into E. coli competent TOP10 cells. Colonies having sufficient insert size were transferred to LB kanamycin freezing medium. Plasmid DNA was isolated with a plasmid mini kit (QIAGEN, Valencia, Calif.) and sequenced, using M13 (-21) forward and M13 reverse primers, on an ABI 3730 (Applied Biosystems, Foster City, Calif.) automatic sequencer at the CAES Genomics Facility, Univ. of California, Davis. For each unique microsatellite locus that contained sufficient reliable flanking sequence on both sides of the microsatellite region, primers for PCR amplification were designed with the primer selection program Primer3 (Rozen and Skaletsky, 2000).

PCR AMPlifiCATION AND PRIMER EVAluATION. Microsatellite primers were initially evaluated for amplification and repeatability of results using four randomly selected ornamental pampas grass plants, and then tested for polymorphism in 16 plants from naturalized populations. DNA amplifications were carried out in a total reaction volume of $12 \mu \mathrm{L}$ containing $20 \mathrm{ng}$ of template DNA, $1 \times$ PCR buffer (QIAGEN) containing $1.5 \mathrm{~mm} \mathrm{MgCl}_{2}, 208 \mathrm{~nm}$ of each primer, $200 \mu \mathrm{M}$ of (each) dNTP, 1 unit of Taq polymerase (QIAGEN). Some reactions required $2 \mu \mathrm{L}$ of 5 м Betain (SigmaAldrich, St. Louis) in the $12 \mu \mathrm{L}$ final volume in order to amplify difficult regions in the genome (Table 2). PCR reactions were performed in an MJ Research PTC-200 thermal cycler (Bio-Rad Laboratories, South San Francisco, Calif.) using the following conditions: an initial denaturation step at $94^{\circ} \mathrm{C}$ for $2 \mathrm{~min}$, followed by 35 cycles of denaturing at $94^{\circ} \mathrm{C}$ for $1 \mathrm{~min}$, annealing at $55^{\circ} \mathrm{C}$ or $60{ }^{\circ} \mathrm{C}$ or $65^{\circ} \mathrm{C}$ (depending on the primer pair) for $1 \mathrm{~min}$, and extension at $72{ }^{\circ} \mathrm{C}$ for $1 \mathrm{~min}$, followed by a final extension step of $30 \mathrm{~min}$ at $72^{\circ} \mathrm{C}$. Touch down PCR used an initial denaturation at $95^{\circ} \mathrm{C}$ for $1 \mathrm{~min}$, followed first by five cycles of denaturation at $94{ }^{\circ} \mathrm{C}$ for $30 \mathrm{~s}$, annealing at $63^{\circ} \mathrm{C}$ for $30 \mathrm{~s}$ with a decrement of $1{ }^{\circ} \mathrm{C}$ per cycle, and extension at $72{ }^{\circ} \mathrm{C}$ for $45 \mathrm{~s}$, followed by 33 cycles of denaturation at $94{ }^{\circ} \mathrm{C}$ for $30 \mathrm{~s}$, annealing at $57^{\circ} \mathrm{C}$ for $30 \mathrm{~s}$, and extension at $72^{\circ} \mathrm{C}$ for $45 \mathrm{~s}$, and a final extension at $72{ }^{\circ} \mathrm{C}$ for $30 \mathrm{~min}$. Amplification products of the initial four test plants were resolved on $2 \%$ agarose gels. Primers that exhibited clear amplification patterns and repeatable results were tested for polymorphism in 16 additional plants and evaluated further on an ABI Prism 3100 Genetic Analyzer (Applied Biosystems).

Determining the precise allelic composition of heterozygous individuals is difficult in allopolyploids such as $C$. selloana unless the microsatellite loci selected for genotyping can be shown to be disomic. To restrict analyses to such loci, we genotyped 56 individuals of $C$. selloana from two large naturalized populations in California where heterozygosity is expected to be high because of the outcrossing nature of pampas grass's breeding system. If no more than two alleles were observed at a locus in all 56 plants genotyped, the locus was considered putatively disomic and used to genotype ornamental pampas grass. 
Microsatellite genOTYPING AND DATA ANALYSIS. Individuals of all cultivars and selections and Cortaderia species were genotyped at 10 polymorphic and putatively disomic microsatellite loci using the nine primer pairs described in Table 2. Microsatellite analyses were conducted on an ABI Prism 3100 Genetic Analyzer (Applied Biosystems) using a 50-cm capillary array loaded with POP7 polymer. PCR reactions were performed as previously described with the exception that forward primers were labeled with the fluorescent dyes 6-FAM, HEX, or NED (Applied Biosystems). PCR products with three different dyes and GENESCAN 400HD (ROX) Size Standard (Applied Biosystems) were run simultaneously on the Genetic Analyzer. Analyses were repeated twice.

Alleles detected at each of the 10 microsatellite loci were automatically sized using GeneMapper software Version 3.7 (Applied Biosystems) and the allelic composition of each individual recorded. Observed heterozy gosity and effective number of alleles were calculated following Hartl and Clark (1997). Pairwise genetic distances were calculated as one minus the proportion of shared alleles (Bowcock et al., 1994) and 1000 bootstrap replications performed using the computer program MICROSATELLITE ANALYSER (Dieringer and Schlötterer, 2003). Distance matrices were imported into PHYLIP version 3.57c (Felsenstein, 2005) and genetic relationships among distinct genotypes, cultivars, and selections depicted by a dendrogram based on the UPGMA clustering algorithm (Sneath and Sokal, 1973).

Cross-SPECIES AMPLIFICATION. The nine primer pairs designed for C. selloana were tested for amplification of microsatellite loci in six other Cortaderia species, namely, C. fulvida, C. jubata, $C$. pilosa, $C$. richardii, $C$. rudiuscula, and $C$. toetoe. DNA extractions, $\mathrm{PCR}$ reactions, and microsatellite analyses were performed as previously described for $C$. selloana.

\section{Results}

ISOLATION AND CHARACTERIZATION OF MICROSATELLITES. The enrichment method based on magnetic bead/biotin capture of repetitive sequences from restricted genomic DNA revealed an abundance of microsatellite loci in the $C$. selloana genome that could be used for marker development. Sequencing 52 clones from the CT-enriched library yielded 45 (86.5\%) inserts with CT repeats. Thirty-eight clones sequenced from the CA-enriched library produced $24(63 \%)$ inserts containing CA repeats. On average, $75 \%$ of sequenced clones contained $(\mathrm{CT})_{n}$ or $(\mathrm{CA})_{n}$ microsatellites with a basic motif greater than 6 repeat units. Of these, $16 \%$ were compound repeats. Seventeen (19\%) clones were exact duplicates, with one clone found in four copies. Seven (7.9\%) inserts were chimeric and similar before or after the microsatellite. In vitro chimera formation between amplification products is not uncommon in allopolyploids because of the presence of two partially homologous templates in one reaction (Cronn et al., 2002). Five sequences were rejected due to the proximity of the microsatellite to the end of the insert. All sequenced clones had adaptors. On average, both genomic libraries contained 8 $(11.7 \%)$ imperfect repeats.

The number of repeats at a locus ranged from 10 to 51 units in the $(\mathrm{CT})_{\mathrm{n}}$ library and from seven to 51 units in the $(\mathrm{CA})_{\mathrm{n}}$ library, excluding the compound sequences in both libraries. Nucleotide sequences of 40 inserts (44.4\% of those sequenced) had sufficient flanking regions available for primer design based on the primer selection program Primer3 (Rozen and Skaletsky, 2000). Primer pairs were designed from these sequences and tested for functionality (amplification and repeatability) in four ornamental pampas grass plants. Twenty-six primer pairs consistently amplified fragments of the expected size. These were initially evaluated for amplification of polymorphic and putatively disomic loci using DNA of 56 individuals from two large naturalized populations of $C$. selloana expected to contain heterozygotes because of the outcrossing nature of the breeding system. Polymorphic loci revealing a maximum of two alleles per individual in all plants examined were considered putatively disomic. In total, nine of the 26 primer pairs amplified 10 putatively disomic loci. The remainder amplified loci with three or more alleles. The 10 putatively disomic loci also revealed a maximum of two alleles in all individuals of the cultivars and selections examined in this study and in an additional 781 individuals genotyped for a separate study of the population genetics of naturalized C. selloana (M. Okada, R. Ahmad, and M. Jasieniuk, unpublished).

Of the nine microsatellite primers, eight primer pairs amplified single loci. One primer pair (Cor-56) amplified two loci per individual (Cor-56-1 and Cor-56-2). We concluded that the primer pair amplified two loci because two sets of alleles were always observed. One or two alleles were present in each of the two regions (loci) in all individuals genotyped. Primer sequences, repeat motifs, and salient features of the microsatellite markers are described in Table 2.

Allelic diversity at microsatellite loci. Eighty-eight individuals representing 17 ornamental pampas grass cultivars and four selections from Europe and the United States (Table 1) were genotyped at 10 microsatellite loci using the nine primer pairs. The number of alleles amplified ranged from two to 19 per locus (Table 2). Locus Cor-43 exhibited the highest allelic number with 19 alleles, followed by Cor- 36 with 18 alleles. In total, 93 alleles were identified in the 88 individuals. Allele sizes ranged from 90 to $406 \mathrm{bp}$. The effective number of alleles $\left(\mathrm{A}_{\mathrm{e}}\right)$ varied from 1.3 to 9.5 per locus. Level of heterozygosity ranged from a low of 0.07 to a high of 0.81 across loci for cultivars and selections, and from 0 to 0.73 for the naturalized populations from La Jolla and Salinas (Table 2). Observed heterozygosity differed substantially between the naturalized populations at several loci. Only one allele was detected for locus Cor-46 in 26 plants from La Jolla and for locus Cor-56-1 in 30 plants from Salinas, resulting in an observed heterozygosity of zero at these loci in the respective populations. Cor-56-2 in the Salinas population exhibited more than two alleles but one had a disproportionately high frequency equal to $97.6 \%$ and resulted in an observed heterozygosity of zero when rounded to two decimal places.

Of the 93 alleles detected (Table 2), 27 were rare and present only once or twice. Only three alleles (208 bp of Cor-46, 239 bp of Cor-47, and 199 bp of Cor-56-1) were observed in high frequencies ranging from 0.64 to 0.88 while three alleles ( 175 bp of Cor-11, 223 bp of Cor-56-2, and 284 bp of Cor-48) were detected in moderate frequencies ranging from 0.40 to 0.60 . In the majority of cases, alleles were separated by steps of two bp, as expected. In a few instances, alleles differed by a single nucleotide possibly due to mutation in the region flanking the microsatellite locus.

Cultivar identification and Genetic relationships. The majority of pampas grass cultivars were unambiguously distinguished from one another by the 10 microsatellite markers, although no single locus could differentiate all cultivars. Of the total 93 alleles detected in this study, the maximum number of unique alleles observed in a single cultivar was 11 in 'Usballata', followed by seven unique alleles in 'Patagonia'. A dendrogram generated using UPGMA cluster analysis depicts genetic rela- 
Table 1. Ornamental pampas grass (Cortaderia selloana) cultivars and selections genotyped in this study.

\begin{tabular}{lllc}
\hline Cultivar or selection & $\begin{array}{c}\text { Method of } \\
\text { propagation }\end{array}$ & $\begin{array}{l}\text { Source of } \\
\text { plant material }\end{array}$ & $\begin{array}{c}\text { Plants genotyped } \\
(\text { no. })^{z}\end{array}$ \\
\hline Albolineata & Clonal & Europe & 1 \\
Andes Silver & Clonal & U.S. & 1 \\
Argenteum & Clonal & Europe, U.S. & $2(1)^{z}$ \\
Carminea Rendatleri & Clonal & Europe & $2(1)$ \\
Evita & Clonal & U.S. & $6(2)$ \\
Gold Band (syn. Aureolineata) & Clonal & Europe, U.S. & $7(6)$ \\
Monvin & Clonal & U.S. & $5(1)$ \\
Patagonia & Clonal & U.S. & 1 \\
Pink & Seed & U.S. & $13(13)$ \\
Pink Feather & Seed & Europe & 1 \\
Pumila & Clonal & Europe, U.S. & $18(8)$ \\
Roi des Roses & Clonal & Europe & 1 \\
Rosea & Seed & U.S. & $6(6)$ \\
Silver Comet & Clonal & U.S. & $8(3)$ \\
Sterile & Clonal & U.S. & 1 \\
Sunningdale Silver & Clonal & Europe, U.S. & $3(2)$ \\
Super Pink & Seed & U.S. & $3(3)$ \\
Usballata & Clonal & U.S. & $3(2)$ \\
Varietat & Clonal & Europe & 1 \\
White & Seed & U.S. & $4(4)$ \\
White Feather & Seed & Europe & 1 \\
\hline
\end{tabular}

${ }^{\bar{z}}$ Number of distinct genotypes are indicated in parentheses unless only one accession was genotyped.

Table 2. Characteristics of the 10 microsatellite markers developed for Cortaderia selloana.

\begin{tabular}{|c|c|c|c|c|c|c|c|c|c|}
\hline SSR & Primer sequence $\left(5^{\prime}-3^{\prime}\right)$ & $\begin{array}{c}\text { Annealing } \\
\text { temp } \\
\left({ }^{\circ} \mathrm{C}\right)\end{array}$ & Repeat & $\begin{array}{c}\text { Allele } \\
\text { size range } \\
\text { (bp) }\end{array}$ & $\begin{array}{c}\text { Putative } \\
\text { alleles } \\
\text { (no.) }\end{array}$ & $\begin{array}{c}\text { Effective } \\
\text { alleles }^{\mathrm{z}} \\
\text { (no.) }\end{array}$ & $\begin{array}{c}\text { Cultivars } \\
\mathrm{H}_{\mathrm{o}}{ }^{\mathrm{y}} \\
(\mathrm{n}=88)\end{array}$ & $\begin{array}{c}\text { La Jolla } \\
\mathrm{H}_{\mathrm{o}}{ }^{\mathrm{x}} \\
(\mathrm{n}=26)\end{array}$ & $\begin{array}{c}\text { Salinas } \\
\mathrm{H}_{\mathrm{o}}{ }^{\mathrm{w}} \\
(\mathrm{n}=30)\end{array}$ \\
\hline \multirow[t]{2}{*}{ Cor-7 } & ACCTCCACAAGGATGACAGG & & & & & & & & \\
\hline & GTCСТССТСАССТCCATCAA & 55 & $(\mathrm{CT})_{37}$ & $251-271$ & 13 & 6.4 & 0.64 & 0.42 & 0.63 \\
\hline \multirow[t]{2}{*}{ Cor-11 } & TTTCTTCAGTTCTGCCACGA & & & & & & & & \\
\hline & TTTGCTGCGAATTGAAGTTG & 55 & $(\mathrm{CT})_{4}(\mathrm{CA})_{8}(\mathrm{CT})_{3}(\mathrm{AT})_{4}$ & $169-210$ & 14 & 4.4 & 0.62 & 0.54 & 0.60 \\
\hline \multirow[t]{2}{*}{ Cor-36 } & TGCACAGTTCACAGGGAAGA & & & & & & & & \\
\hline & ACTTGTCTGTCCCCGTAAATAAA & 55 & $(\mathrm{CT})_{21}$ & $335-406$ & 18 & 8.9 & 0.81 & 0.58 & 0.59 \\
\hline \multirow[t]{2}{*}{ Cor-43 } & GATGGAAATGCCTGGAGAGA & & & & & & & & \\
\hline & $\begin{array}{l}\text { TGGAACCCCAACAGAAGCTA } \\
\text { TGACAGTGATCCCTGACTGG }\end{array}$ & 55 & $(\mathrm{CA})_{35}$ & $90-242$ & 19 & 9.5 & 0.68 & 0.73 & 0.57 \\
\hline Cor-46 & CGCTAGATCCTTGAGCGTTT & 55 & $(\mathrm{CA})_{9}$ & $205-214$ & 6 & 1.7 & 0.15 & 0 & 0.63 \\
\hline \multirow[t]{2}{*}{ Cor-47 } & AGCTTCAGGTCTGCTTCTCACT & & & & & & & & \\
\hline & $\begin{array}{l}\text { TGGTATCGTGCATCAAAGTTTC } \\
\text { GAGAAAGGGGTGGGTCATTT }\end{array}$ & 65 & $(\mathrm{CA})_{7}$ & $234-241$ & 4 & 2.1 & 0.18 & 0.27 & 0.33 \\
\hline Cor- $48^{v}$ & $\begin{array}{l}\text { GGCCAAGGAGGACAAAAGTA } \\
\text { TCCCACATGTCAGTGGAGTG }\end{array}$ & 55 & $(\mathrm{~A})_{20}$ & 284-309 & 4 & 2.2 & 0.43 & 0.23 & 0.20 \\
\hline Cor-49 & GCATGTGTGATGCCGATG & 57 u & $(\mathrm{CT})_{13}$ & $115-137$ & 8 & 4.5 & 0.48 & 0.62 & 0.30 \\
\hline \multirow[t]{2}{*}{ Cor-56-1 } & CACCCAACCAATATCCCTGT & & & & & & & & \\
\hline & TTTCACCCTCTGTTTTTCGTT & 55 & $(\mathrm{CA})_{9}$ & 199-202 & 2 & 1.3 & 0.07 & 0.38 & 0 \\
\hline Cor-56-2 & Same as Cor-56-1 & 55 & $(\mathrm{CA})_{9}$ & $221-226$ & 5 & 3.1 & 0.49 & 0.23 & 0 \\
\hline
\end{tabular}

${ }^{2}$ Effective number of alleles in cultivars and selections was calculated as the reciprocal of $\sum p_{i}{ }^{2}$ where $p_{i}$ is the frequency of the $i$ th allele.

yHeterozygosity observed in cultivars and selections.

xHeterozygosity observed in naturalized population from La Jolla, Calif.

wHeterozygosity observed in naturalized population from Salinas, Calif.

vequired $2 \mu \mathrm{L}$ of $5 \mathrm{~m}$ Betain in $12 \mu \mathrm{L}$ reaction volume.

uTouch down PCR.

tionships among cultivars and clearly shows that most pampas grass cultivars could be distinguished from one another (Fig. 1). Only two sets of cultivars had identical multilocus genotypes and could not be differentiated. One set consisted of 'Roi des Roses' and 'Carminea Rendatleri'. The second set consisted of 'Argenteum', 'Varietat', and an accession of 'Sunningdale Silver' from the United States.
Six major groups of cultivars had bootstrap support exceeding $50 \%$ (Fig. 1). High bootstrap values ( $\geq 95 \%$ ) strongly supported identification of 'Gold Band' and 'Silver Comet', and the cluster consisting of 'Evita' and accessions of 'Pumila' from Europe ('Pumila' EU) plus one 'Pumila' accession from the United States ('Pumila' US). Interestingly, the remaining 'Pumila' US accessions formed a separate cluster with moderate bootstrap support, 


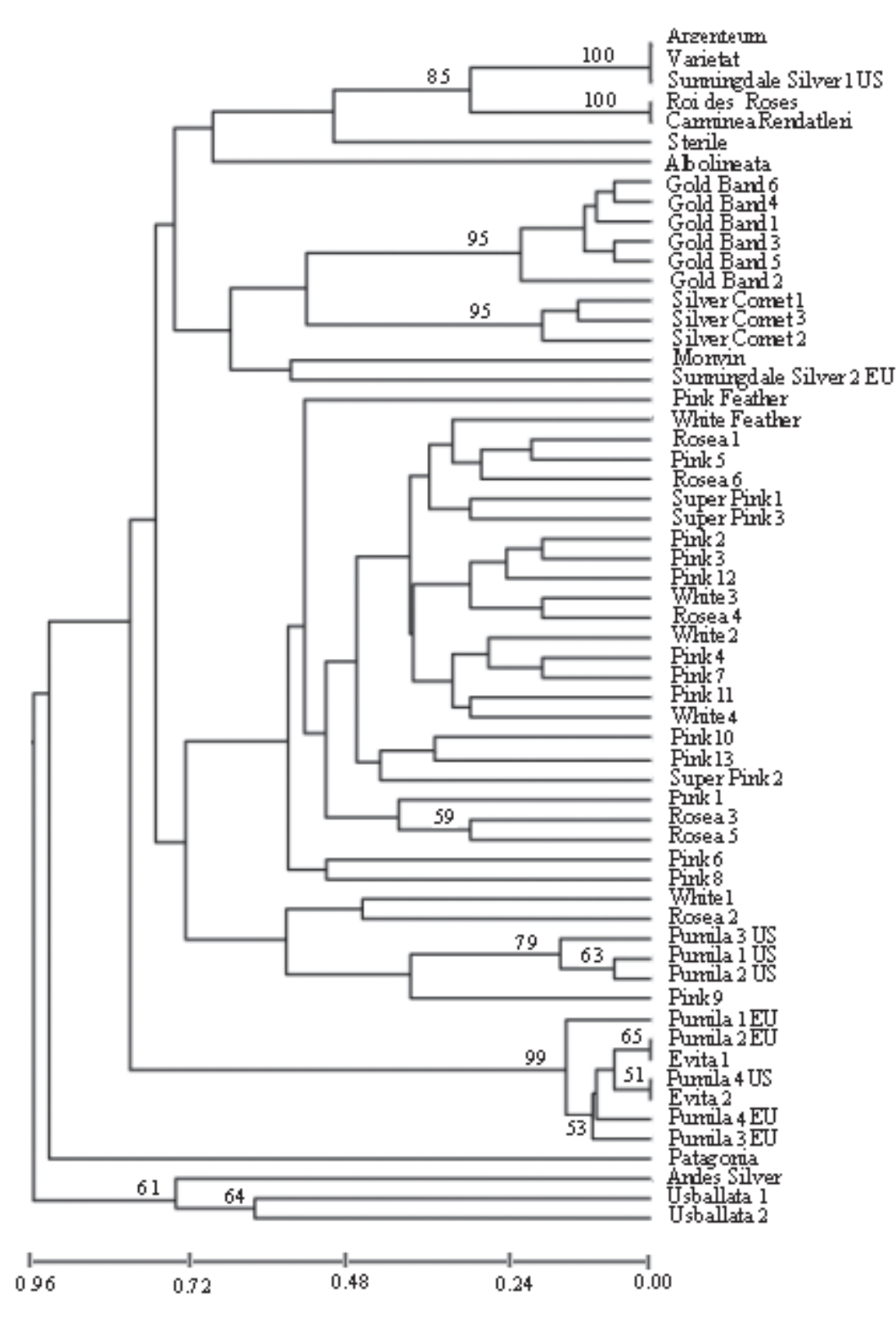

Fig. 1. Dendrogram generated using UPGMA cluster analysis based on the proportion of shared alleles at 10 microsatellite loci among Cortaderia selloana genotypes representing 17 cultivars and four selections. Bootstrap values out of 1000 replicates are shown if $50 \%$ or higher.

C. fulvida, six primers (66\%) amplified nine alleles of which four were common to C. selloana. The efficiency of cross-amplification was 55\% in the remaining cultivars $C$. toetoe and $C$. richardii. In $C$. toetoe, the five primers amplified 10 alleles of which five were common to $C$. selloana. In $C$. richardii, the five primers amplified and revealed nine alleles of which four were common to C. selloana.

\section{Discussion}

To our knowledge, this study is the first to isolate and characterize microsatellite loci in ornamental pampas grass and the genus Cortaderia. Microsatellite loci were identified from small insert genomic libraries derived from $C$. selloana and enriched for CA and CT repeats. The enrichment procedure, based on hybridization of genomic DNA to biotintylated microsatellite oligonucleotides (Ahmad et al., 2003; Hamilton et al., 1999), was highly successful. Of the 90 clones sequenced, $76 \%$ contained at least one microsatellite with a basic motif greater than six CA or CT repeat units. The library efficiency, as measured by the percentage of clones containing microsatellites, was higher or comparable to that obtained in other studies using similar enrichment by hybridization protocols (see Maguire, 2001 for a cursory review). A higher percentage (86.5\%) of inserts from the CT-enriched library contained microsatellites than from the CA-enriched library (63\%), which is consistent with database surveys showing that $(\mathrm{AT})_{n}$ and $(\mathrm{CT})_{n}$ repeat motifs occur most frequently in plant genomes (Lagercrantz et al., 1993; Morgante and Olivieri, 1993; Wang et al., 1994). Although (CA) repeats are reported to be rare overall, they have been found in significant numbers in genomes of grass species (Cordeiro et al., 2000; Jones et al., 2001; Liu et al., 1995; Saal and Wricke, 1999) and were also found to be abundant in pampas grass.

Seventeen of the 90 clones sequenced in this study were exact duplicates and one clone was found in four copies. The level of redundancy observed in this study is lower than reported in many others, e.g. $40 \%$ in Phleum pratense L. (Cai et al., 2003), $40 \%$ in Helianthus annuus L. (Tang et al.,

equaling $79 \%$. The three remaining clusters with bootstrap support greater than $50 \%$ include the cluster of two sets of cultivars with identical multilocus genotypes ('Argenteum', 'Varietat', 'Sunningdale Silver' US; and 'Roi des Roses' and 'Carminea Rendatleri'), a cluster consisting of two genotypes of 'Rosea', and a cluster consisting of 'Andes Silver' and 'Usballata'. Most of the remaining pampas grass genotypes form a large cluster with low bootstrap support (less than 50\%) that includes the three cultivars Pink Feather, White Feather, and Rosea and the three selections Pink, Super Pink, and White.

Cross-species amplification. The microsatellite primers designed for C. selloana also amplified loci in other Cortaderia species (Table 3 ). All nine primer pairs (100\%) amplified loci in the apomictic $C$. jubata and revealed 18 alleles in the six plants genotyped of which $13(72 \%)$ were common to C. selloana. Seven (77\%) primers amplified loci in C. pilosa and C. rudiuscula. In
2002), 29\% in Humulus lupulus L. (Brady et al., 1996), 24\% in Melaleuca alternifolia (Maiden \& Betche) Cheel (Rossetto et al., 1999), and similar to the $22 \%$ observed in Olea europaea L. (Carriero et al., 2002) and $16 \%$ in Lolium perenne L. (Jones et al., 2001). Redundancy is likely to increase as more clones are sequenced from the same enriched library.

Microsatellite loci selected for marker development and cultivar identification in ornamental pampas grass exhibited considerable polymorphism. The large number of alleles $(\geq 13)$ observed for four of the 10 loci is higher or comparable to the number observed in many ornamental plants (e.g., Becher et al., 2000; Esselink et al., 2003; Smulders et al., 2003). The effective number of alleles $\left(\mathrm{A}_{\mathrm{e}}\right)$ at a locus (Hartl and Clark, 1997) is a measure of information content and indicates the discriminatory power of a locus. Cor- 43 was the most informative locus with 9.5 alleles; locus Cor-56-1 was the least discriminatory with 1.3 
Table 3. Cross-species amplification of Cortaderia selloana microsatellite primers. ${ }^{\mathrm{z}}$

\begin{tabular}{|c|c|c|c|c|c|c|c|c|c|c|}
\hline $\begin{array}{l}\text { Cortaderia } \\
\text { species }\end{array}$ & Cor-7 & Cor-11 & Cor-36 & Cor-43 & Cor-46 & Cor-47 & Cor- 48 & Cor-49 & Cor-56 & $\begin{array}{c}\text { Primers } \\
\text { amplified } \\
(\%)\end{array}$ \\
\hline$\overline{C . j u b a t a}$ & $+\mathrm{y}$ & + & + & + & + & + & + & + & + & 100 \\
\hline C. pilosa & + & + & n.a. ${ }^{x}$ & + & + & + & n.a. & + & + & 77 \\
\hline C. rudiuscula & + & + & n.a. & + & + & + & n.a. & + & + & 77 \\
\hline C. fulvida & n.a. & + & n.a. & + & + & + & + & n.a. & + & 66 \\
\hline C. richardii & + & n.a. & n.a. & + & n.a. & + & + & n.a. & + & 55 \\
\hline C. toetoe & n.a. & + & n.a. & + & + & + & n.a. & n.a. & + & 55 \\
\hline
\end{tabular}

${ }^{\mathrm{z}}$ Each amplification was repeated at least twice.

${ }^{y_{+}}=$successful amplification.

${ }^{x}$ n.a. $=$ no amplification.

alleles. Observed heterozygosity varied widely among loci in both cultivated plants and the naturalized populations examined. The large number of alleles detected and the range of variation in heterozygosity observed clearly indicate that the microsatellite markers developed here will be useful for genotyping both cultivated and naturalized ornamental pampas grass.

The cultivars and selections examined in this study represent the most common ornamental pampas grass types cultivated in Europe and North America. The majority of these were distinguished by the 10 microsatellite loci despite the variety of sources (Europe, U.S., nurseries, botanical gardens, internet sites) of plant material and the multiple genotypes detected among different accessions of most cultivars and selections (Fig. 1). Only two clusters of cultivars exhibited identical genotypes. One group consisted of 'Argenteum', 'Varietat', and 'Sunningdale Silver'. These cultivars are nearly identical in phenotype with elegant silvery plumes (Greenlee, 1992; Grounds, 1998) and most likely represent progenitor and derivative relationships in sport selections. The second consisted of 'Carminea Rendatleri' and 'Roi des Roses'. Both are pink-flowered cultivars and among the earliest named. The two groups of cultivars with identical genotypes formed a cluster with moderately high bootstrap support (85\%) indicating close genetic relationship despite phenotypic differences in plume color.

Based on our collections, 'Monvin' exhibited the greatest genetic uniformity among accessions. The five plants genotyped in this study, obtained from four different nurseries, were of identical genotype (Table 1) and thus represented by a single genotype in Fig. 1. 'Monvin' is a relatively new pampas grass cultivar and the only one to be patented. It was commercially released by Monrovia Nursery Co. (Azusa, Calif.) in 1991 (Darke, 1999, 2004; Greenlee, 1992). 'Monvin' has a characteristic yellow stripe down the center of the leaf and is marketed under the name Sun Stripe (Monrovia Nursery Co.).

The remaining cultivars with strong genetic identity, based on bootstrap values exceeding 90\% in Fig. 1, include 'Gold Band', 'Silver Comet', and the cluster consisting of 'Pumila' and 'Evita'. 'Gold Band' and 'Silver Comet' are cultivars with yellow and white foliage variegation. 'Gold Band' is a male clone that was introduced to the United States about 20 years ago from England, where it was previously known as 'Aureolineata' or 'Yellow Stripes' (Hornback, 1994). Today, the cultivar is sold under the name 'Gold Band' on both continents. 'Silver Comet' is a whitestriped female cultivar that is relatively new to North America and has more pronounced variegation than the long-established white-striped cultivar Albolineata (syn. 'Silver Stripe') sold in Europe (Darke, 1999, 2004; Hornback, 1994). The remaining cluster with strong bootstrap support consists of 'Pumila' and
'Evita'. 'Pumila' is a dwarf female cultivar that flowers freely and is commonly grown in small gardens (Greenlee, 1992; Grounds, 1979, 1998). 'Evita' is a sport of 'Pumila' and about half its size (Hornback, 1994). Of the five 'Pumila' genotypes in this cluster, four were acquired from Europe ('Pumila' EU) and one from the United States ('Pumila' US). Three additional genotypes named 'Pumila' from the United States formed a separate cluster with moderate bootstrap support (79\%). The genetic differences between 'Pumila' fromEurope and the United States suggest separate origins of the cultivar in the two geographic regions.

A large, diverse group in Fig. 1 consists of the pink-flowered cultivars Rosea and Pink Feather and selections Pink and Super Pink as well as the white-flowered cultivar White Feather and selection White. With the exception of two individuals of 'Rosea,' the cluster has low bootstrap support $(<15 \%)$ consistent with a diverse collection of genotypes that lack strong cultivar identity. Individuals in this group are sold as seed rather than clonal plants (Table 1). Sexual reproduction and hybridization among cultivars and selections are likely to account for much of the variation in this group. In contrast, cultivars with strong identity, as indicated by high bootstrap values in Fig. 1, are vegetatively propagated and sold as potted or bare-root clones. Interestingly, all but one of the individuals of 'Pumila' acquired in the United States clustered with this diverse group of cultivars and selections. The presence of 'Pumila' US in this group, separated from the group of 'Pumila' sold in Europe ('Pumila' EU), suggests independent origins of the cultivar in the two geographic regions. This hypothesis is further supported by the observation that 13 of 14 alleles detected in the 'Pumila' US cluster are shared with the remaining cultivars and selections in the Pink-White group. The American 'Pumila' is thus likely to have originated from this group. The one allele (151 bp of Cor-43) in 'Pumila' US not found in the remainder of the group is uniquely shared with 'Gold Band' suggesting possible introgression of the latter cultivar into 'Pumila' US.

In the UPGMA analysis, the cultivars Patagonia, Andes Silver, and Usballata formed two groups that are distinct from the remaining pampas grass cultivars and selections. The three cultivars are derived from $C$. selloana native to the foothills of the Andes in contrast to the majority of cultivars, which are derived from plants of the Argentinean pampas (Hornback, 1994; Madison, 1992).

In addition to distinguishing pampas grass cultivars, the microsatellite primers developed in this study also revealed variation in amplification across species in the genus Cortaderia. The pattern of cross-amplification was concordant with phylogenetic relationships previously inferred from DNA sequence variation in nuclear internal transcribed spacer(ITS) regions and the chloroplast $r p o \mathrm{C} 2$ gene (Barker et al., 2003). In the ITS and rpoC2 consensus tree, 
C. selloana, C. jubata and C. rudiuscula belonged to one clade (Cortaderia from South America) while C. fulvida, C. richardii, and $C$. toetoe were part of the New Zealand lineage. Each clade had high bootstrap support (100\%) (Barker et al., 2003). In our study, a higher proportion of microsatellite primers developed for C. selloana amplified loci in the more closely related South American $C$. jubata and $C$. rudiuscula than the more distantly related $C$. fulvida, $C$. richardii, and $C$. toetoe from New Zealand. The ITS and rpoC2 phylogeny showed considerable resolution among distantly related species of Cortaderia. However, the resolution among closely related species such as those within section Cortaderia was weak and attributed to low levels of sequence divergence as a consequence of recent and/or on-going diversification (Barker et al., 2003). The variation in amplification of microsatellite primers across and within the South American and New Zealand lineages observed in this study suggests that these microsatellite loci and flanking DNA sequences may be useful for further study of the phylogenetic relationships among species within the paraphyletic Cortaderia.

In summary, we successfully isolated microsatellite loci from the genome of $C$. selloana and developed 10 polymorphic, and putatively disomic, markers that can be used to identify cultivars of ornamental pampas grass. The microsatellite markers provide new tools for the breeding and selection of novel cultivars, assessments of cultivar identity and purity, and studies of the genetic diversity and structure of native and naturalized populations worldwide. In addition, the cross-amplification and transferability of these markers to other species of Cortaderia may be useful for comparative genetic and phylogenetic studies.

\section{Literature Cited}

Ahmad, R.,D. Struss, and S.M. Southwick. 2003. Development and characterization of microsatellite markers in citrus. J. Amer. Soc. Hort. Sci. 128: 584-590.

Barker, N.P., H.P. Linder, C.M. Morton, and M. Lyle. 2003. The paraphyly of Cortaderia (Danthonioideae; Poaceae): Evidence from morphology and chloroplast and nuclear DNA sequence data. Ann. Missouri Bot. Gardens 90:1-24.

Becher, S.A., K. Steinmetz, K. Weising, S. Boury, D. Peltier, J-P. Renou, G. Kahl, and K. Wolf. 2000. Microsatellites for cultivar identification in Pelargonium. Theor. Appl. Genet. 101:643-651.

Bowcock, A.M., A. Ruiz-Linares, J. Tomfohrde, E. Minch, J.R. Kidd, and L.L. Cavalli-Sforza. 1994. High resolution of human evolutionary trees with polymorphic microsatellites. Nature 368:455-457.

Brady, J.L., N.S. Scott, and M.R.Thomas. 1996. DNA typing of hops (Humulus lupulus) through application of RAPD and microsatellite marker sequences conserved to sequence tagged sites (STS). Euphytica 91:277-284.

Cabrera, A.L. 1953. Manual de la flora de los Alrededores de Buenos Aires. Editorial Acme, Buenos Aires, Argentina.

Cai, H-W., N. Yuyama, H. Tamaki, and A. Yoshizawa. 2003. Isolation and characterization of simple sequence repeat markers in the hexaploid forage grass timothy (Phleum pratense L.). Theor. Appl. Genet. 107:1337-1349.

Carriero, F., G. Fontanazza, F. Cellini, and G. Giorio. 2002. Identification of simple sequence repeats (SSRs) in olive (Olea europaea L.). Theor. Appl. Genet. 104:301-307.

Chase, M.W. and H.H. Hills. 1991. Silica gel: An ideal material for field preservation of leaf samples for DNA studies. Taxon 40:215-220.

Connor, H.E. 1973. Breeding systems in Cortaderia (Gramineae). Evolution 27:663-678.

Connor, H.E. 1983. Cortaderia (Gramineae): Interspecific hybrids and the breeding systems. Heredity 51:395-403.

Connor, H.E. and E. Edgar.1974. Names and types in Cortaderia Stapf (Gramineae). Taxon 23:595-605.

Cordeiro, G.M., G.O. Taylor, and R.J. Henry. 2000. Characterization of microsatellite markers from sugarcane (Saccharum sp.) a highly polyploid species. Plant. Sci. 155:161-168.

Costas-Lippmann, M. 1976. Ecology and reproductive biology of the genus Cortaderia in California. PhD Diss., Univ. of California, Berkeley.

Costas-Lippmann, M. 1977. More on the weedy pampas grass in California. Fremontia 4:25-27.
Cronn, R., M. Cedroni, T. Haselkorn, C. Grover, and J.F. Wendel. 2002. PCRmediated recombination in amplification products derived from polyploid cotton. Theor. Appl. Genet. 104:482-489.

Darke, R. 1999. The color encyclopedia of ornamental grasses. Timber Press, Portland, Ore.

Darke, R. 2004. Timber Press pocket guide to ornamental grasses. Timber Press, Portland, Ore.

Dieringer, D. and C. Schlötterer. 2003. MICROSATELLITEANALYSER(MSA): A platform independent analysis tool for large microsatellite data sets. Mol. Ecol. Notes 3:167-169.

DiTomaso, J.M., E. Healy, C.E. Bell, J. Drewitz, and A. Tschohl. 1999. Pampasgrass and jubatagrass threaten California coastal habitats. Univ. Calif. Weed Res. Info. Ctr. Coop. Ext. Lflt. 99-1.

Doyle, J.J. and J.L. Doyle. 1987. A rapid DNA isolation procedure for small amounts of fresh leaf tissue. Phytochem. Bul. 19:11-15.

Esselink, G.D., M.J.M. Smulders, and B. Vosman. 2003. Identification of cut rose (Rosa hybrida) and rootstock varieties using robust sequence tagged microsatellite site markers. Theor. Appl. Genet. 106:277-286.

Felsenstein, J. 2005. PHYLIP (Phylogeny inference package) version 3.57c. 4 Mar. 2006. <http:/evolution.genetics.washington.edu/phylip.html>

Greenlee, J. 1992. The encyclopedia of ornamental grasses. Rodale Press, Emmaus, $\mathrm{Pa}$.

Grounds, R. 1979. Ornamental grasses. Pelham Books Ltd., London.

Grounds, R. 1998. The plantfinder's guide to ornamental grasses. Timber Press, Portland, Ore.

Hamilton, M.B., E.L. Pincus, A. Di Fiore, and R.C. Fleischer. 1999. Universal linker and ligation procedures for construction of genomic DNA libraries enriched for microsatellites. Biotechniques 27:500-507.

Hartl, D.L. and A.G. Clark. 1997. Principles of population genetics. $3^{\text {rd }}$ ed. Sinauer, Sunderland, Mass.

Hitchcock, A.S. and A. Chase. 1950. Manual of the grasses of the United States. $2^{\text {nd }}$ ed. U.S. Dept. Agr. Misc. Publ. 200.

Hornback, B. 1994. In praise of pampas grass. Pacific Hort. 56:47-52.

Jones, E.S., M.P. Dupal, R. Kölliker, M.C. Drayton, and J.W. Forster. 2001. Development and characterization of simple sequence repeat (SSR) markers for perennial ryegrass (Lolium perenne L.). Theor. Appl. Genet. 102:405-415.

Lagercrantz, U., H. Ellegren, and L. Andersson. 1993. The abundance of various polymorphic microsatellite motifs differs between plants and vertebrates. Nucleic Acids Res. 21:1111-1115.

Liu, Z.W., R.L. Jarret, S. Kresovich, and R.R. Duncan. 1995. Characterisation and analysis of simple sequence repeat (SSR loci) in seashore paspalum (Paspalum vaginatum Swartz.). Theor. Appl. Genet. 91:47-52.

Lyle, M. 1996. Change in name and status of a pampas grass (Cortaderia, Poaceae: Arundinoideae) from Bolivia. Novon 6:72-77.

Madison, J. 1992. Pampas grasses: One a weed and one a garden queen. Pacific Hort. 54:48-53.

Maguire, T.L. 2001. Producing and exploiting enriched microsatellite libraries, p. 193-209. In: R.J. Henry (ed.). Plant genotyping: The DNA fingerprinting of plants. CABI, New York.

Morgante, M. and A.M. Olivieri. 1993. PCR-amplified microsatellites as markers in plant genetics. Plant J. 3:175-182.

Oakes, A.J. 1990. Ornamental grasses and grasslike plants. Van Nostrand Reinhold, New York.

Robinson, E.R. 1984. Naturalized species of Cortaderia (Poaceae) in southern Africa. South African J. Bot. 3:343-346.

Rossetto, M., A. McLauchlan, F.C.L. Harriss, R.J. Henry, P.R. Baverstock, L.S. Lee, T.L. Maguire, and K.J. Edwards. 1999. Abundance and polymorphism of microsatellite markers in the tea tree (Melaleuca alternifolia, Myrtaceae). Theor. Appl. Genet. 98:1091-1098.

Rozen, S. and H. Skaletsky. 2000. Primer3 on the WWW for general users and for biologist programmers, p. 365-386. In: S. Krawetz and S. Misener (eds.). Bioinformatics methods and protocols in the series methods in molecular biology. Humana Press, Totowa, N.J.

Saal, B. and G. Wricke. 1999. Development of simple sequence repeats in rye (Secale cereale L.). Genome 42:964-972.

Smulders, M.J.M., Y. Noordijk, W. Rus-Kortekaas, G.M.M. Bredemeijer, and B. Vosman. 2003. Microsatellite genotyping of carnation varieties. Theor. Appl. Genet. 106:1191-1195.

Smyth, W. 1908. Ornamental grasses (Gramineae). J. Royal Hort. Soc. 33:107. Sneath, P.H.A. and R.R. Sokal. 1973. Numerical taxonomy: The principles and practice of numerical classification. Freeman, San Francisco.

Tang, S., J-K.Yu, M.B. Slabaugh, D.K. Shintani, and S.J. Knapp. 2002. Simple sequence repeat map of the sunflower genome. Theor. Appl. Genet. 105:1124-1136.

Wang, Z., J.L. Weber, G. Zhong, and S.D. Tanksley. 1994. Survey of plant short tandem DNA repeats. Theor. Appl. Genet. 88:1-6. 